\title{
Dagusibu Di Era Covid-19 Bagi Kader Kesehatan Lasivmu Pengurus Sedayu
}

\author{
Sabtanti Harimurti*, Pinasti Utami, Nurul Maziyyah \\ Program Studi Farmasi, Fakultas Kedokteran dan Ilmu Kesehatan \\ Universitas Muhammadiyah Yogyakarta \\ Jl. Brawijaya, Tamantirito, Kasihan, Bantul, Yogyakarta, Indonesia, 55183 \\ Email: sabtanti@umy.ac.id \\ DOI: $10.18196 / p p m .32 .157$
}

\begin{abstract}
Abstrak
DAGUSIBU merupakan program nasiolah dari Ikatan Apoteker Indonesa dalam menggerakkan masyarakat dalam pemakaian obat dengan baik dan benar. Program ini meliputi mengajarkan bagainama mendapatkan obat dengan baik, menggunakan obat dengan baik, menyimpan obat dengan baik dan membuang/memusnahkannya obat dengan baik apabila sudah tidak digunakan atau sudah melebihi masa kadaluwarsanya. Seiring dengan meningkatnya penyakit degeneratif dimasyarakat khususnya darerah Sedayu, yang menyebabkan meningaktnya jumlah pasien yang bisa dirawat dirumah, maka pengetahuan orang yang merawat pasein tentang pemakaian obat perlu diperhatikan. Hal ini ditujukan agar pengobatan untuk pasien yang dirawat dirumah mencapati tujuannya. Untuk itu, pimpinan cabang Muhammadiyah Sedayu unit kegiatan LazizMu membentuk kader kesehatan yang diharapkan bisa membantu para perawat pasien. Karena pentingnya pengetahuan akan obat-obatan, maka para kader dibekali materi tentang DAGUSIBU. Pembekalan dilakukan dengan cara sosialisasi yang kemudian dievaluasi dengan pre-test dan post-test dan pemantavan setelah pelaksanaan sosialisasi. Berdasarkan hasil pre-test dan post-test,peningkatan pemahaman akan DAGUSIBU meningkat sebesar 9,57\% setelah dilakukan sosilaisai. Setelah satu bulan berlalu dan dilakukan pemantauan pemahaman tetang DAGUSIBU, diperoleh keterangan bahwa dari 4 kader yang memberikan jawaban menyatakan bahwa pemahaman DAGUSIBU sangat bemanfaat ketika mengelola obat di masa pandemic COVID 19.
\end{abstract}

Kata Kunci: DAGUSIBU, kader kesehatan, LazizMu, Muhammadiyah

\section{Pendahuluan}

Organisasi Muhammadiyah adalah oraganisasi yang banyak bergerak di bidang pendidikan dan kesehatan yang berlandaskan keislaman (Nashir,2001). Gerakan Muhammadiyah dimulai dari Pimpinan Ranting Muhammadiyah dan Pimpinan Cabang Muhammadiyah (Majalah SM Edisi 3 Tahun 2019) Gerakan Cabang Muhammadiyah Sedayu, Bantul, Yogyakarta di bidang kepedulian sosial dan kesehatan baru saja dirintis November 2019 dengan dibentuknya LazisMu PCM Sedayu. LazisMu PCM Sedayu masih memiliki beberapa keterbatasan seperti sumber daya manusia, rancangan program, dan jejaring kerjasama dengan amal usaha Muhammadiyah lainnya. Sejalan dengan meningkatnya populasi pasien penyakit kronis seperti: kanker, penyakit paru obstruktif krobik (PPOK), HIV AIDS, Diabetes Mellitus dengan komplikasi, stroke, gagal ginjal, gangguan jantung, demensia (pikun) yang dirawat di rumah di tengah keluarga dan masyarakat menjadi tantangan bagi kader Muhammadiyah daerah Sedayu. Dalam perawatnnya, tentunya tidak lepas dari penggunaan obat-obatan. Penggunaan obat-obatan yang rasional tentunya akan sangat membantu dalam tujuan perawatan pasien (Stewart RB and Cooper, 1994). Oleh karena itu, salah satu bentuk konkrit untuk menjawab tantangan tersebut adalah dengan dibentuknya kader kesehatan (Notoatmojo, 2010; Aderita dan Chotimah, 2018). Kader kesehatan ini akan menjadi suber bertanya dan memahamkan tetang penggunaan obat yang rasional kepada masyarakat luas. Prodi Farmasi FKIK UMY yang mempunyai visi yang salah satunya adalah menjadi pusat layanan informasi obat, maka kami ingin membagikan ilmu kefarmasian kepada kader muda Muhammadiyah di daerah Sedayu. Dengan demikian, masyarakat Sedayu akan lebih paham dan bisa mempraktekkan DAGUSIBU (dapatkan, gunakan, simpan, dan buang) yang merupakan program nasional dari IAI (Ikatan Apoteker Indonesia) untuk mengkampanyekan penggunaan obat yang rasional (PP IAI, 2014). Program ini dicanangkan untuk mendukung ketercapaian pengobatan yang efektif dan efisien. Untuk itu kami menggandeng LazisMU sebagai mitra pengabdian masyarakat dalam program pengabdian dengan judul Kader Muda Muhammadiyah Peduli DAGUSIBU. Adapun tujuan dari pengabdian masyarakat ini adalah terbentuknya kader kesehatan Muhammadiyah Sedayu yang siap menjadi 
mitra bagi institusi pelayanan kesehatan untuk meningkatkan kualitas hidup pasien penyakit kronis dan terminal.

\section{Metode Pelaksanaan}

Hal pertama yang dilakukan adalah merekrut kader kesehatan di tiap ranting Muhammadiyah di wilayah kerja LasizMu Sedayu, dan orang umum yang bersedia dan siap menjadi kader Muhammadiyah serta berkomitmen untuk menyelesaikan pembimbingan tenang DAGUSIBU. Bahan pembimbingan adalah 1. Bagaimana mendapatkan obat yang benar?; 2. Bagaimana menggunakan obat yang benar?; 3. Bagaimana menyimpan obat yang benar?; dan 4. Bagaimana membuang obat yang tidak terpakai? Untuk mengukur keberhasilan pelatihan, diselenggarakan pre-tes dan post-tes, serta pemantauan pemahaman dan sebulan setelah pelatih. Berhubungan dengan masa pandemic Covid 19, pelatihan hanya bisa diselenggarakan dalam 120 menit secara offline oleh 16 peserta pada tanggal 15 Maret 2020 di saat social distancing belum diterapkan. Pengabdian ditutup dengan menyerahkan hibah pengabdian berupa buku panduan DAGUSIBU dan kotak obat berserta isinya.

\section{Hasil dan Pembahasan}

Hal pertama yang dilakukan adalah merekrut kader kesehatan di tiap ranting Muhammadiyah di wilayah kerja LasizMu Sedayu, dan orang umum yang bersedia dan siap menjadi kader Muhammadiyah serta berkomitmen untuk menyelesaikan pembimbingan tenang DAGUSIBU. Bahan pembimbingan adalah 1. Bagaimana mendapatkan obat yang benar?; 2. Bagaimana menggunakan obat yang benar?; 3. Bagaimana menyimpan obat yang benar?; dan 4. Bagaimana membuang obat yang tidak terpakai? Untuk mengukur keberhasilan pelatihan, diselenggarakan pre-tes dan post-tes, serta pemantauan pemahaman dan sebulan setelah pelatih. Berhubungan dengan masa pandemic Covid 19, pelatihan hanya bisa diselenggarakan dalam 120 menit secara offline oleh 16 peserta pada tanggal 15 Maret 2020 di saat social distancing belum diterapkan. Pengabdian ditutup dengan menyerahkan hibah pengabdian berupa buku panduan DAGUSIBU dan kotak obat berserta isinya.

\section{HASIL DAN PEMBAHASAN}

\section{Karakteristik kader Kesehatan}

Pelatihan kader muda Muhammadiyah peduli DAGUSIBU sudah dilaksanakan pada tanggal 15 Maret 2020 (Gambar 1). Tempat pelaksanaan pelatihan adalah di Masjid Darussalam, Ngentak, Sedayu, Bantul, Yogyakarta. Peserta yang mengikuti pelatihan adalah sebayak 16 orang terdiri dari kader muda Muhammadiyah yang berasal dari ranting-ranting Muhammadiyah di Wilayah kerja LazizMu Sedayu. Pelaksanaan pelatihan adalah dengan memberikan materi terkait DAGUSIBU. Karekteristik dari para kader secara detail adalah dijelaskan sebagai mana urain berikut.

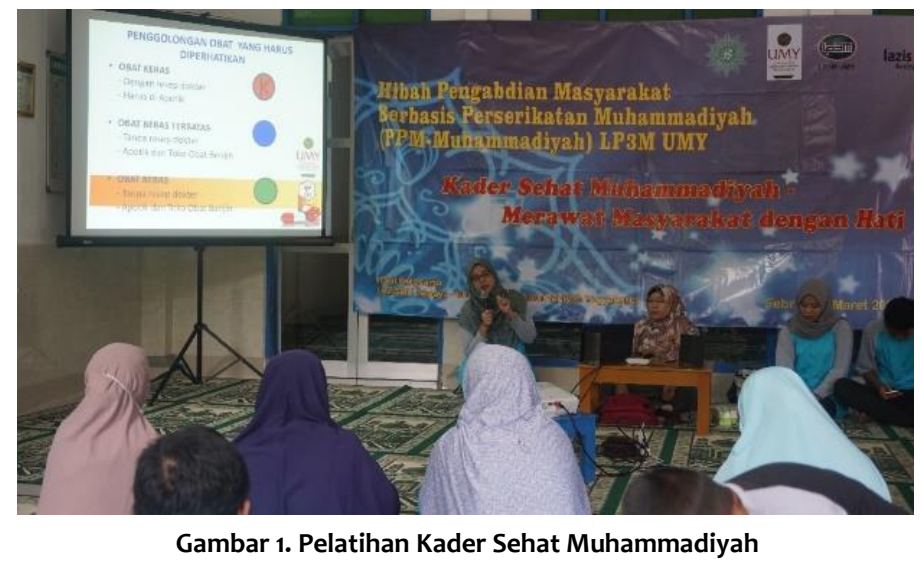




\section{Usia}

Usia dari para kader kesehatan Muhammadiyah yang ikut dalam pelatihan adalah antara 19 56 tahun (Gambar 2). Menurut Depkes RI tahun 2009, peserta pealatihan masuk dalam kategori Remaja akhir sampai kategori lansina akhir. Peserta terbanyak adalah dalam kategori dewasa akhir yaitu pada usia 36 - 45 tahun. Tabel 1 berikut adalah pengelompokan umur berdasarkan Depkes RI tahun 2009.

\begin{tabular}{cc}
\multicolumn{2}{c}{ Tabel 1. Pengelompokan Umur menurut Depkes RI $\mathbf{2 0 0 9}$} \\
\hline Kriteria & Usia (tahun) \\
\hline Masa Balita & $0-5$ \\
Masa Kanak-kanak & $5-11$ \\
Masa remaja awal & $12-16$ \\
Masa remaja akhir & $17-25$ \\
Masa dewasa awal & $26-35$ \\
Masa dewasa akhir & $36-45$ \\
Masa lansia awal & $46-55$ \\
Masa lansia akhri & $56-65$ \\
Masa manula & $65-$ sampai atas \\
\hline
\end{tabular}

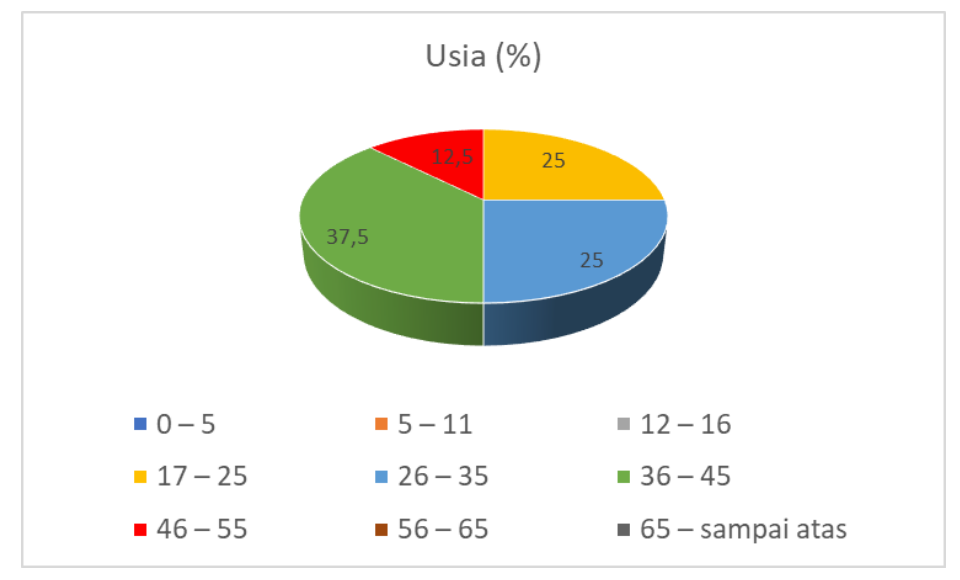

Gambar 2. Prosentase jumlah peserta pelatiahan DAGUSIBU berdasarkan kategori usia menurut Depkes RI tahun 2009.

\section{Jenis kelamin}

Peserta pelatihan yang terbanyak berjenis kelamin perempuan yang mencapai $75 \%$. Prosentase banyaknya kader berjenis kelamin perempuan seperti Gambar 3. Banyaknya perempuan yang bersedia menjadi kader kesehatan dimungkinkan karena naluriah perempuan yang suka merawat. 


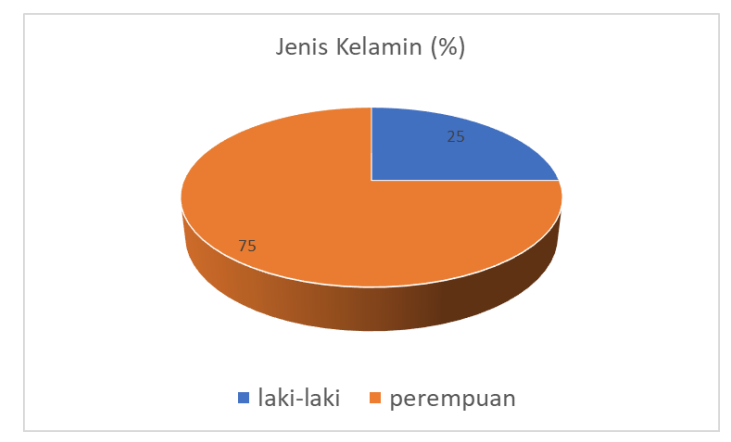

Gambar 3. Prosentase jenis kelamin peserta pelatihan

\section{Pekerjaan}

Peserta pealtihan kader muda Muhammadiyah peduli DAGUSIBU mempunyai pekerjaan sebagai mahasiswa, ibu rumah tangga, pegawai negri, wiraswata, swasta non nakes dam PNS non nakes. Dari semua pekerjaan yang dimiliki oleh para kader, prosentase terbesar adalah Swasta non nakes yang mencapai 56,25\%, disusul oleh mahasiswa dan wiraswasta mencapai masing-masing 12,55, dan terakhir adalah ibu rumah tangga, PNS non nakes, dan pegawai negri yang masing-masing mencapai 6,25 (Gambar 4). Kelompok terbesar adalah yang mempunyai pekerjaan swasta non nakes, hal ini dimungkinkan jenis pekerjaan ini memerlukan jadwal yang fleksibel sehingga merasa mampu mengtur waktunya untuk bisa bekerja sebagai kader kesehatan.

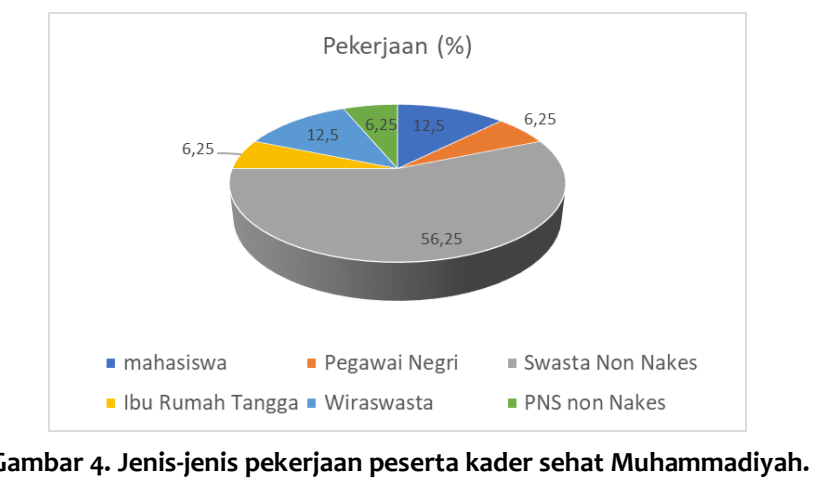

\section{Penghasilan}

Penghasilan merupakan salah satu hal yang dijadikan karakter bagi para kader sehat muahmmadiyah. Gambar 5 adalah pengkategorian besaran penghasilan para kader. Kelompok terbesar mempunyai penghasilan $<500$ ribu perbulan. Hal ini merupakan kelompok dari ibu rumah tangga, swasta non nakes dan wiraswata. Kelompok ini dimungkinkan mempunyai waktu yang cukup fleksibel sehingga mau menjadi kader kesehatan. Tetapi ada juga yang mempunyai penghasilan diatas 2 juta rupiah yaitu yang mempunyai pekerjaan sebagai PNS non nakes. Kader ini bersedia menjadi kader kesehatan dimungkinkan karena panggilan hari untuk bisa berkirprak didalam pergerakan meningkatkan derajat kesehatan masyarakat disekitarnya. 


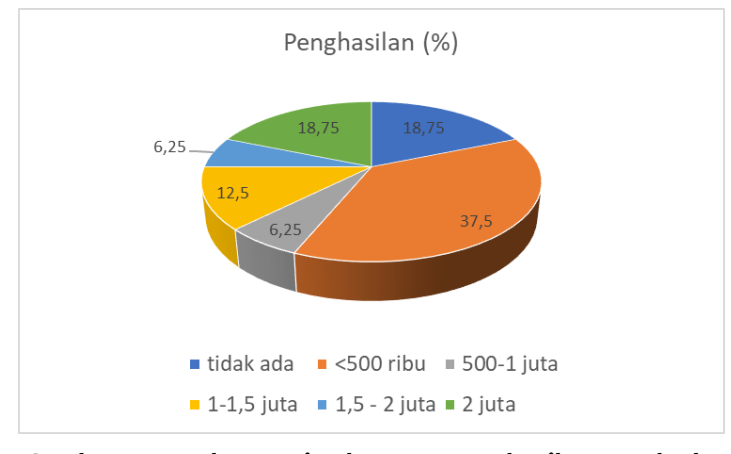

Gambar 5. Pengkategorian besaran penghasilan para kader

\section{Pendidikan}

Pendidikan para kader sehat seperti terlihat pada Gambar 6. Kelompok terbesar mempunyai Pendidikan terakhir SMA (43\%), disusul sajana (31,25\%), diploma (18\%) dan terakhir pasca sarjana $(6,25 \%)$. Tingkat pendidikan sangat penting sebagai dasar pelatihan kader kesehatan. Apabila terlalu rendah, maka akan kesulitan dalam menerima materi-materi yang disampaikan terkait DAGUSIBU, karena akan muncul istilah-istilah yang kemungkinan belum diterima pada pendidikan rendah.

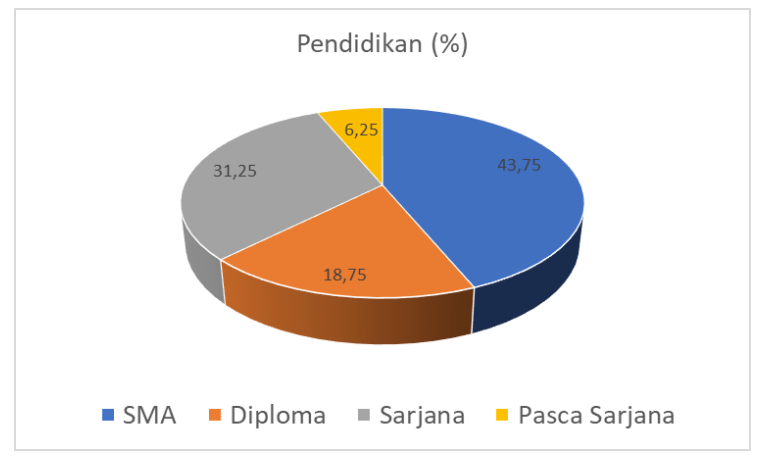

Gambar 6. Tingkat pendidikan kader kesehatan Muhammadiyah.

\section{Evaluasi pemahaman materi DAGUSIBU}

Evaluasi tercapainya pelatihan dilakukan dengan mengadakan pre-tes dan post-test. Karakteristik dan hasil pre-test dan post-test bisa dilihat pada tabel 2. Pada tabel 2 bisa dilihat karakterisik kader yang yaitu jenis kelamin, umur, pekerjaan, pendidikan, peghasilan, dan besarnya peningkatan pemahaman setelah pelatihan tentang bagaimana mendapatkan obat yang benar, menggunkaan obat dengan benar, menyimpan obat dengan benar, dan membuang obat dengan benar. Pemahaman dinilai dengan pre-dan post-test tentang DAGUSIBU sebanyak 32 pertanyaan. Prosentase peningaktan pemahaman adalah diukur dengan menghitung selisih jawaban benar saat post-test dan pre-test dibagi jumlah soal kemudian dikalikan seratus.

Tabel 2. Karakteristik dan hasil pre-test dan post-test

\begin{tabular}{|l|l|l|l|l|l|l|l|l|}
\hline Kader & $\begin{array}{l}\text { Jenis } \\
\text { Kelamin }\end{array}$ & Umur & Pendidikan & Pekerjaan & Penghasilan & $\begin{array}{l}\text { Jawaban } \\
\text { Betul } \\
\text { Pre-Test } \\
(\%)\end{array}$ & $\begin{array}{l}\text { Jawaban } \\
\text { Betul Post- } \\
\text { Test }(\boldsymbol{\%})\end{array}$ & $\begin{array}{l}\text { Peningkatan } \\
\text { Pemahaman } \\
(\%)\end{array}$ \\
\hline 1 & Perempuan & 56 & SMA & $\begin{array}{l}\text { Swasta non } \\
\text { nakes }\end{array}$ & $<500$ ribu & 50,00 & 62,50 \\
\hline 2 & Perempuan & 19 & Sarjana & Mahasiswa & $<500$ ribu & 90,63 & 90,63 \\
\hline 3 & Laki-laki & 37 & SMA & $\begin{array}{l}\text { Swasta non } \\
\text { nakes }\end{array}$ & 2 juta & 46,88 & 78,13 & 31,25 \\
\hline
\end{tabular}




\begin{tabular}{|c|c|c|c|c|c|c|c|c|}
\hline 4 & Perempuan & 25 & Diploma & $\begin{array}{l}\text { Swasta non } \\
\text { nakes }\end{array}$ & $1,5-2$ juta & 68,75 & 87,50 & 18,75 \\
\hline 5 & Perempuan & 35 & SMA & $\begin{array}{l}\text { Swasta non } \\
\text { nakes }\end{array}$ & $1-1,5$ juta & 68,75 & 78,13 & 9,38 \\
\hline 6 & Perempuan & 35 & Diploma & Wiraswasta & $<500$ ribu & 71,88 & 81,25 & 9,38 \\
\hline 7 & Perempuan & 45 & SMA & $\begin{array}{l}\text { Swasta non } \\
\text { nakes }\end{array}$ & $<500$ ribu & 62,50 & 65,63 & 3,13 \\
\hline 8 & Laki-laki & 40 & $\begin{array}{l}\text { Pasca } \\
\text { Sarjana }\end{array}$ & $\begin{array}{l}\text { PNS non } \\
\text { Kesehatan }\end{array}$ & 2 juta & 75,00 & 87,50 & 12,50 \\
\hline 9 & Laki-laki & 30 & SMA & $\begin{array}{l}\text { Swasta non } \\
\text { nakes }\end{array}$ & $1-1,5$ juta & 81,25 & 81,25 & 0 \\
\hline 10 & Perempuan & 35 & SMA & $\begin{array}{l}\text { Ibu Rumah } \\
\text { Tangga }\end{array}$ & - & 81,25 & 87,50 & 6,25 \\
\hline 11 & Perempuan & 39 & Sarjana & $\begin{array}{l}\text { Swasta non } \\
\text { nakes }\end{array}$ & $<500$ ribu & 65,63 & 81,25 & 15,63 \\
\hline 12 & Perempuan & 30 & SMA & $\begin{array}{l}\text { Swasta non } \\
\text { nakes }\end{array}$ & 2 juta & 65,63 & 81,25 & 15,63 \\
\hline 13 & Perempuan & 45 & Sarjana & Wiraswasta & 500-1 juta & 59,38 & 75,00 & 15,63 \\
\hline 14 & Laki-laki & 23 & Diploma & Pegawai Negri & - & 84,38 & 81,25 & $-3,13$ \\
\hline 15 & Perempuan & 45 & Sarjana & $\begin{array}{l}\text { Swasta non } \\
\text { nakes }\end{array}$ & - & 87,50 & 84,38 & $-3,13$ \\
\hline 16 & Perempuan & 21 & Sarjana & Mahasiswa & $<500$ ribu & 84,38 & 93,75 & 9,38 \\
\hline \multicolumn{6}{|c|}{ Total } & 71,48 & 81,05 & 9,57 \\
\hline \multicolumn{9}{|c|}{ Jumlah soal pertanyaan 32} \\
\hline
\end{tabular}

Secara keseluruhan, besarnya presentase peningkatan pemahaman tentang DAGUSIBU setelah dilakuakan pelatiahan adalah sebesar 9,57\%. Hal ini sejalan dengan hasil penelitian tentang pemahaman DAGUSIBU yang dilaksnakan di Desa Kedungbanteng Banyumas, yaitu setalah dilakukan sosilasi tengang cara mendapatkan, menggunakan, menyimpan dan membuang obat jumlah peserta yang mendapatkan nilai 80-100 (kategori paham) meningakt menjadi $30 \%$ orang dari 1\% (Suryoputri \& Sunarto, 2019). Secara detail, nilai terendah dari pretest dan post-test adalah kader dengan karakteristik perempuan, berumur 56 thaun, pendiikan SMA, pekerjaan swata non nakes dan mempunyai penghasilan kurang dari 500 ribu perbulan. Nilai pre-test yang diperoleh adalah $50,00 \%$ dan nilai post-test yang diperoleh adalah $62,50 \%$.

Apabila dilihat dari karakter kader, nilai rendah ini dimungkiankan karena usia yang sudah memasuki akhir lansia, sehingga kemampuan untuk menyerap materi menjadi berkurang. Kader termuda yang berumur 19 tahun yang merupakan mahasiwa mempunyai nilai pre-test dan posttest paling tinggi yaitu 90,63\%. Hal ini dimungkinkan bahwa pekerjaannya sebagai mahasiswa menjadikannya memperoleh nilai tertinggi. Evaluasi lain yang dilakukan bagi para kader adalah evaluasi pemahaman tentang DAGUSIBU dan kebermanfaatannya program pelatihan DAGUSIBU dimasa pandemic Covid 19. Dari 4 kader yang memberikan pernyataan tentang kepahaman cara mendaptakan, menggunakan, menyimpan dan membuang obat serta kepahaman tentang pengelolaan obat dirumah dimasa pandemic covid 19 melalui google form, bisa disimpulkan bahwa dari 4 kader tersebut memahami dengan baik tentang cara mendaptakan, menggunakan, menyimpan dan membuang obat serta kepahaman tentang pengelolaan obat dirumah dimasa pandemic covid 19.

\section{Simpulan}

Hasil pembimbingan DAGUSIBU kepada para kader kesehatan di wilayah kerja LazizMu Sedayu meningkatkan pemahaman pengetahuan DAGUSIBU sebanyak 9,57\% dan dari hasil pemantauan 1 bulan setelah pelaksanaan pembimbingan didapati dari 4 kader yang memberikan balasan memahami DAGUSIBU dengan baik selama masa pandemic COVID 19. Pemantauan akan pemahaman dan upadate DAGUSIBU sebaiknya dilakukan secara regular, caranya dengan 
membuat grup di media social seperti WA, yang mana disitu akan dipantau dan diupade pengetahuannya tentang DAGUSIBU.

\section{Ucapan Terima Kasih}

Penulis mengucapkan terimakasih yang sebesar-besarnya kepada Universitas Muhammadiyah Yogyakarta yang telah memberikan fasilitas dan dana untuk pelaksanaan kegiatan ini. Penulis juga mengucapkan terimakasih kepada LazisMu PCM Sedayu yang sudah menjadi mitra dalam pelaksanan kegiatan ini.

\section{Daftar Pustaka}

Aderita, N. I., \& Mulia, C. C. P. B. (2018). Peran kader kesehatan dalam tindakan penemuan kasus Tuberkulosis dengan pendekatan theory planned of behaviour di wilayah kerja Puskesmas Bendosari. IJMS-Indonesian Journal on Medical Science, 5(2).

Chang, V. T., Arnold, R. M., \& Savarese, D. (2017). Approach to symptom assessment in palliative care. Hentet fra https://www. uptodate. com/contents/approach-tosymptomassessment-in-palliative care, 14-150.

Den Hartogh, G. (2017). Suffering and dying well: on the proper aim of palliative care. Medicine, Health Care and Philosophy, 20(3), 413-424.

Depkes, R. I. (2009). Profil Kesehatan Indonesia 2008. Jakarta: Departemen Kesehatan Republik Indonesia.

Kompasiana, Jangan Sembarangan Membuang Obat, Kenali "Dagusibu" agar Obat Anda Tak $\begin{array}{llll}\text { Disalahgunakan, } & 14 & \text { Februari } & 2018\end{array}$ (https://www.kompasiana.com/irmina.gultom/5a83fd8cbde5750d2b58a844/dagusibuedukasi-tentang-obat-yang-sederhana-namun-penting?page=all.

Lamrous, A. (2018). Medecins Sans Frontieres (MSF). Palliative care: "Ourmission is also to alleviate suffering". https://www.msf.org/palliative-care-ourmission-also-alleviatesuffering. Diakses pada 18 Mei 2019.

Majalah SM Edisi 3 Tahun 2019, Pimpinan, diakses pada Senin, September 28, 2020. https://www.suaramuhammadiyah.id/2020/04/18/pimpinan/

Nashir, H. (2001). Ideologi Gerakan Muhammadiyah. Suara Muhammadiyah.

Nasional, D. P. (2019). Kamus besar bahasa Indonesia.

Notoatmodjo, S. (2010). Konsep Perilaku Kesehatan Dalam: Promosi Kesehatan Teori \& Aplikasi edisi revisi. Jakarta: RinekaCipta.

PP IAI. 2014. Pedoman Pelaksanaan Gerakan Keluarga Sadar Obat.Pengurus Pusat Ikatan Apoteker Indonesia. Jakarta.

Stewart, R. B., \& Cooper, J. W. (1994). Polypharmacy in the aged. Drugs \& aging, 4(6), 449461.

Suryoputri, M. W., \& Sunarto, A. M. (2019). Pengaruh Edukasi Dan Simulasi Dagusibu Obat Terhadap Peningkatan Keluarga Sadar Obat Di Desa Kedungbanteng Banyumas. JATI EMAS (Jurnal Aplikasi Teknik dan Pengabdian Masyarakat), 3(1), 51-55. 